\title{
Fiscal Austerity Versus Growth in Croatia
}

\author{
Marinko Škare', Romina Prziklas Druzeta'
}

\begin{abstract}
The role of fiscal austerity has been questioned for centuries, but a rapidly increasing deficit along with the financial crisis in 2007/2008 influenced a renewed debate on the economics of austerity. This paper analyzes the role of austerity versus the role of economic growth. It also attempts to highlight the role of the theoretical context of austerity policy and the economic history lesson learned during the transition from the Bretton Woods model to Washington's consensus.

Despite numerous studies and polarized debate, no consensus on the implementation of fiscal austerity has been achieved because this complex subject has not been the subject of a sufficient methodological exploration. Emphasis should be placed on defining the methodology of austerity and gathering statistical data to influence the implementation of social transfer policies. In addition, it is necessary not only to take a hybrid approach to fiscal and monetary policy but also to adopt economic laws and quantitative economic relationships. The benchmarking country used in this paper is Croatia. The outcome of this research can serve as the basis for future decision-making and research.
\end{abstract}

KEY WORDS: $\quad$ fiscal austerity; economic growth; business cycles; macroeconomic adjustments

JEL Classification: $\quad$ 01, O2, E62, E63, F43

${ }^{1}$ Juraj Dobrila University of Pula - Faculty of economics and Tourism "Dr. Mijo Mirkovic", Croatia

\section{Introduction}

The concept of "fiscal austerity" and its adjustment has attracted considerable attention in recent years. This focus on fiscal austerity is of particular importance, especially in transitional countries affected by declining GDP, decreasing wages and social protections, increasing inequality, balance-of-payments difficulties, and a sharply declining aggregate demand. The EU's authority over new Member States includes the authority to monitor national fiscal policies to impose new rules. Governments expected to avoid creating deficits

Correspondence concerning this article should be addressed to: Marinko Škare Juraj Dobrila University of Pula - Faculty of economics and Tourism "Dr. Mijo Mirkovic" Preradoviceva 1/1 Pula Istarska zupanija 52100 Croatia T: 38552377057 F: 38552377013 E-mail:mskare@unipu.hr and to reduce their public debt to a "sustainable level". National governments' primary economic goals-to achieve long-term prosperity and to maintain employment that contributes to long-term economic growth-were sacrificed to achieve a balanced budget and to reduce the national debt. Different countries have followed are different paths to austerity. Although international debates usually focus on issue affecting the PIGS countries (Portugal, Ireland, Greece, Spain), the UK, Germany and major economies such as the USA, Japan, and France (which enjoy a higher fiscal capacity, exercise political sovereignty and use a world currency), this paper's benchmark country is Croatia. This paper analyzes the role of austerity versus the role of economic growth. It also attempts to highlight the role of the theoretical context of austerity policy and the economic history lesson learned during the transi- 
tion from the from Bretton Woods model to Washington's consensus. Despite numerous studies responding to the issues of whether governments should adopt austerity despite their weak economies and whether balanced budgets can ensure sustainable economic growth, because these complex issues have not been the subjects of a sufficient methodological exploration, there is no consensus-only a polarized debate.

The dramatically negative experiences of the PIIGS countries' European debt crisis and the vulnerability of the Croatian economy indicate the need for a methodological investigation to determine whether there are other forms of adjustment that focus on employment growth and prosperity. To achieve the moderate scenario of a "Goldilocks economy", it is necessary to build an optimal model of economic growth and to forecast that model based on knowledge of economic rules and quantitative economic relationships. In this way, crises and economic cycles can be foreseen and managed. Thus, just as in Keynes's proposal that depending on the period of an economy's business cycle, the implementation of austerity should be emphasized (Keynes, 1936). In addition, it is necessary to require a hybrid approach to fiscal and monetary policy. To ensure sustainable growth in light of the budget deficit, it is of the utmost importance to implement appropriate redistributive policies based on the macroeconomic indicators that reflect societies' well being. In the $21^{\text {st }}$-century context in which human relationships are becoming increasingly complex, scholars and scientists must reconsider the position of human beings in the contexts of new technologies, science, global economics, social relations and future prospects. Consequently, a multidisciplinary approach is always required (Sharma, 2013). The outcome of this research could affect transitional countries' immediate decision-making related to the implementation of social policies. It could also serve as the basis for further research. Its implications, limitations and directions for further research are offered. This paper is structured into four sections. Section I analyzes the theoretical context of austerity policy and the lessons of economic history. Section II provides background research. Section III analyzes austerity versus growth using the example of Croatia. Section IV presents concluding remarks and policy recommendations.

\section{The theoretical framework of austerity policy versus economic growth}

The phenomenon of austerity economics has been the subject of scientific research for centuries. According to Konzelman (2012), no general agreement has emerged from the polarized debate about the economics of austerity about what austerity is, when it should be applied or in whose interest it is presumed to operate. Austerity measures therefore include some combination of public expenditure reductions and increased taxes. The aim of economic austerity is to reduce a country's deficit-i.e., the difference the government's revenues and expenses. The economics of reaffirming austerity and the economics of the deficit-financing problem were greatly influenced by the emergence of the Industrial Revolution in the mid18th and 19th centuries, WWI (1914-1918), WWII (1939-1945) and the global financial crisis of 20072008. Early debates on austerity economics focused on the role of facilitating the financing of national emergencies, such as wars and national defense. With capitalism's evolution, the debate has shifted toward the state's expectations and the use of public debt. More specifically, the turbulent economic events of the 1970s produced a change in economic theory and policy. The transition from the Bretton Woods model to the Washington consensus, along with the incorporation of monetarism into government policy, imposed radical changes and prompted the adoption of new rules. Although the Washington consensus was primarily designed as a development model for Latin American countries and did not deliver the expected results-inequality of both income and wealth distribution increased along with poverty, economic and financial crises-subsequently it was applied as the development model for the post-communist transition economies of Central and Eastern Europe that were confronted by with structural problems associated with de-industrialization, slow economic growth, declining productivity and the like during the transition process. A new economic turn has occurred under the influence of several factors.

The 1973 oil crisis and drastic increase in oil prices caused worldwide inflation, lower production and decreased employment decline). Furthermore, Bretton Woods collapsed; the era of fixed exchange rates ended 

Ireland, Greece, Spain) countries and the impending collapse of the European Monetary Union. The global financial crisis that began in 2007 in the United States, the European debt crisis that culminated in 2010 and the general crisis of $21^{\text {st }}$-century capitalism have theoretically revived Keynes and Marx and have prompted new discussions between state interventionists and those committed to the idea of market liberalism. Despite numerous studies, no heterodox model that could serve as an economic panacea has been found. The financial crisis has been reflected in high fiscal deficits, increasing debt, and a decline in aggregate demand and production, all of which have had a negative impact on employment and have deepened both inequality and poverty, especially in transitional countries that are confronted by structural problems. To simultaneously reduce both fiscal deficits and the public debt, governments have shifted their policy from fiscal stimulus to austerity. However, according to Alfred Calcagno (2012), if slow growth or recession is caused by insufficient demand, a new round of fiscal tightening will further depress economic activity. As a result, governments will reduce tax revenues and increase social expenditures without guarantee that fiscal balances will improve. In the infancy of the global financial and economic crisis, the Croatian economy-which has been confronted by structural problems since the transition-was affected. Although the transitional countries have functioned completely differently from the developed economies, primarily due to business-cycle fluctuations (developed economies have time series of a few hundred years) because of the escape of capital, decision-making systems etc., global trade liberalization and deregulation has substantially affected small, open countries such as Croatia. Because the current policy goal is to restrain the public debt and inflation and to comply with European Union rules (i.e., the budget deficit must not exceed 3\% of GDP and the public debt must not exceed $60 \%$ ) despite high unemployment, inequality, poverty, economic contractions and economic vulnerability, there is a question of how to turn toward full employment and long-term economic prosperity. According to Zaman et al. (2014), the government officials and policy makers should reopen the debate about propoor-growth policies pursuant to which wealth trickles down to the poor.
The neoliberal model that advocates austerity even in weak economies and despite the diversity of the national economies that are simultaneously adopting austerity has become questionable in both Europe and the United States.

\section{Fiscal austerity problems in review}

Recently, the literature on fiscal austerity and fiscal adjustment has attracted considerable attention. However, studies and research lead to transversal views.

The focus on austerity is of particular importance in transitional countries because the costs of transition are reflected in GDP contraction; balance-of-payment difficulties; falling wages, employment, and social protection; and increasing inequality and social insecurity, especially for those at the bottom of the scale. Therefore, a frequently mentioned issue in recent studies is "Should governments adopt austerity despite their weak economies or can balancing the budget ensure sustainable economic growth"?

Konzelmann (2012) has reviewed the historical experience of how the world economy has attempted to address austerity and macroeconomic imbalances and has concluded that the economics of austerity cannot be meaningfully separated from austerity's social and political context. The author supports Keynes's idea of the impact of business cycles on the application of austerity, that is, on the use of deficit spending to stimulate economic growth and employment during a prolonged recession. Given the current course of austerity policy, Konzelmann questions why a government would pursue an austerity policy in the context of economic recession when there is no economic basis for austerity and persistent macroeconomic imbalances threaten to further destabilize the global economy. She finds an answer in the political and economic impact of liberalized global financial markets. Specifically, Konzelman notes that under neoliberalism, fiscal policy is guided by the interests of the wealthy and the private-sector financial elite. According to her, the demand for austerity measures proves that a national government can manage its deficits and repay its debts, thus demonstrating that austerity is not a policy aimed at macroeconomic stabilization: austerity itself is the target policy. She concludes that if economic austerity continues to undermine macroeconomic performance, financial markets are unlikely to support 
the affected countries. What is missing from the ongoing debates about austerity is recognition not only that stimulus/incentive is not the only alternative to austerity policy but also that reducing the public debt and the deficit can be achieved by reducing public spending and by increasing tax revenues. Simultaneously, she stresses that future public spending can be divided into current and capital spending, which have significantly different macroeconomic effects.

According to Blyth (2013), austerity is a form of voluntary deflation in which the economy is adjusted by reducing wages, prices and public spending to restore competitiveness, which is (supposedly) best achieved by cutting the state's budget, debts and deficits. Blyth criticizes austerity as an economic policy and notes that the austerity measures proposed to ensure the stability of the Eurozone countries have done exactly the opposite. As an example, he cites the PIIGS (Portugal, Ireland, Italy, Greece, Spain) countries, which implemented austerity measures in response to the $2008 \mathrm{fi}$ nancial crisis, believing that economic growth would return if they slashed their budgets and reduced their debt. However, that scenario was nowhere close to accurate. According to Blyth, austerity is a dangerous idea because it ignores increasing inequality (people at the bottom of the scale, who most often cure debt with more debt, tend to be the most affected), the paradox of saving (i.e., if everybody saves money at the same time, there will be no investment-stimulating spending) and different externalities. Furthermore, he states that the budget deficit follows business cycles, which are cyclical-not secular. Observing the crisis period in the United States, European Union and Eastern Europe reveals that the crisis was generated by the private sector but it was paid for by the public sector. He concludes that in the future, financial repression and high taxes on top earners will become a part of the landscape. We will be forced to solve our debt problems in this way because austerity simply does not work.

Papadimitriou and Hannsgen (2012), in a paper researching how the Eurozone countries have fared under austerity, note that austerity is the wrong policy at the wrong time. They conclude that austerity has brought pain, not relief, to the Eurozone. Austerity has resulted in slow growth, rising unemployment, declining aggregate demand and falling profits. The authors support Keynes's argument that the right time for aus- terity is during a boom, not a slump; they also make proposals. Their general approach is to propose tax cuts that primarily benefit the wealthy, which would help to loosen fiscal policy for little social purpose rather than a macroeconomic one. They support increased programmatic spending aimed at solving key problems, along with tax cuts and transfers to individuals and families with the highest needs and lowest saving rates. They hope that a large proportion of the new spending would be used in ways that increase employment.

According to Ogujiuba and Ehigiamusoe (2014), the government should reduce wasteful non-development-related spending financed by domestic and foreign borrowing and instead should allocate more resources for developing the education, health, and infrastructure sectors of the economy.

In his book "Bad Samaritans", Chang (2008) notes that the emphasis on fiscal restraint is the central theme of neoliberal macroeconomic policy. He notes that Southern Korea, which was a "sorry country" during the 1960s, is now one of the wealthiest countries in the world. Its progress is the result of a mixture of market incentives and government administration. Chang also states that although neoliberal founders will attribute Korea's success to the belief that Korea adopted a neoliberal economic development strategy (a free market, low inflation, private enterprise, free trade, and foreign investments) during the "miracle years" between the 1960s and the 1980s, the reality is significantly different. Korea based its development on new industries selected by the government in consultation with the private sector, using customs protection, subsidies and other forms of state support. The government owned all of the banks and therefore could direct business loans. If private companies were not doing well, the government felt free to restore state-owned companies, which it would often restructure or resell. The government also protected heavy industries with tariffs and subsidies. However, tariff protection and subsidies were not used to protect industries from international competition but to buy time to absorb new technologies and establish new organizational skills until industries could compete on the world market. In conclusion, the author states that the "Korean miracle" was based on correcting the market through interventionist policy. The contribution of "Bad Samaritans" is 
to argue that that neoliberal policy propagated by the "Bad Samaritans" who promote an ethos of "do as we say, not as we did" can be very harmful to economic growth and development.

Chang's (2011) book "23 Things They Don't Tell You About Capitalism" argues that the huge budget deficits created by the crisis will force governments to significantly reduce public investments and welfare entitlements, negatively affecting economic growth, poverty and social stability-possibly for decades. He concludes that this catastrophe was ultimately created by the free-market ideology that has ruled the world since the 1980s. Although, he emphasizes that being critical of free-market ideology is not the same as being anti-capitalism. His criticism is of a particular version of capitalism-free-market capitalism-that has dominated the world for three decades.

According to Calcagno (2012), austerity policies are based not only on an incorrect diagnosis of the nature and depth of the crisis but also on an erroneous view of economic mechanisms. A strategy of cutting education, research and infrastructure investments will deliver neither growth nor competitiveness. The implicit identification of fiscal tightening with fiscal consolidation shows the deficiency of the macroeconomic approach. The author notes that if slow growth or recession is due to insufficient demand, a new round of fiscal tightening will further depress economic activity that will reduce tax revenues and increase social expenditures with no guarantee that fiscal balance will be restored. Additionally, by deepening the recession, larger parts of the financial system may need government support, which would cause fiscal accounts to become dramatically disoriented. Thus, he concludes that governments that criticize "living above their means" often forget that government expenditure and revenues are linked. Furthermore, he notes that only a recovery in growth, with nominal GDP expanding at rates higher than interest rates in the medium and long terms will abate debt-to-GDP ratios. Such growth can result from coordinated supportive policies, which may include changes in the level and composition of public income and expenditures and a better distribution of income and credit that would expand fiscal multipliers and the purchasing power of low- and medium-income groups with a high propensity to consume. His analysis highlights that fiscal tighten- ing has become almost a universal recommendation, despite countries' different structures and levels of development. For instance, high fiscal deficits and rapidly growing debt ratios resulted from the crisis, but only in developed economies: in most developing and transition economies, the debt-to-GDP ratio resumed its downward trend following recovered growth and in many cases, the terms of trade resulted in new gains. He follows recent studies (UNCTAD 2011, Box, 3.2.) which found that expansionary fiscal policy has a positive and significant effect on the level of economic activity, spending multipliers are larger than tax-cut multipliers, and tax cuts benefiting lower-income households have a stronger effect than tax cuts benefiting high-income households. Another recent study from (International Monetary Fund [IMF], 2012) admits that fiscal adjustment may have a substantial impact on activity because fiscal multipliers may be quite large during a recession, when the traditional crowding-out argument is less applicable. In conclusion, fiscal austerity and wage compression have become part of the problem, not the solution. Moreover, there are enough instruments available to pursue pro-growth policies, including, e.g., monetary policy, income policies and instruments, including specific structural and institutional reforms that are better suited to national goals. Monetary policy can still be better targeted, which means that less attention should be paid to the global amount of money than to who gets the money and how they use it. In addition, income policy may be used to stimulate domestic demand. Income policies aimed at reversing the declining trend in the wage share of national income may prove a decisive stimulus to demand and restart growth. For many households, debt is the only way to maintain or increase consumption. This article also follows Aglietta's (2012) critique, according to which the solution for Eurozone countries will come not from additional fiscal tightening or dismantling the welfare state but instead from deeper fiscal and financial integration and a cooperative approach to economic rebalancing. Calcagno concludes that it is most important for deficit countries to avoid self-defeating austerity and to find a way to stimulate their economies; surplus economies must contribute by leading the expansionary response to the global crisis. Therefore, according to the author, structural reforms cannot substitute for supportive macroeco- 
nomic policies to recover economic growth because they may not deliver the expected result.

Constantinos and Nellis (2013) provide a critical assessment of austerity measures that are being implemented in crisis-stricken countries of the Eurozone; in particular, they discuss the implications of internal devaluation for the Greek economy. They challenge theoretical underpinnings and the expected impact of Greece's pursuit of an internal devaluation policy under an austerity framework forced on the country by the so-called "troika" (the European Central Bank (ECB), the European Commission (EC), and the International Monetary Fund (IMF)). In their opinion, austerity measures should be relaxed. The contractionary effects of fiscal policy should be eased and refocused on reducing unemployment by channeling public-sector spending toward viable, socially desirable investment projects. There is also a need for centrally managed European fiscal policy to effectively transfer resources between richer and poorer regions, thus insulating member states from undesirable economic shocks. Their proposals to fundamentally reform regional and industrial policies and to have the European Investment Bank immediately introduce a major program of investments-particularly in the most crisis-stricken economies of Europe's southern region-by issuing euro bonds. This type of program will provide the leeway required for Europe's distressed Southern economies and help them slowly return to the path to recovery. Finally, they make a strong argument that the troika must immediately reconsider the enforcement of fiscal austerity and fiscal consolidation measures. They suggest an alternative economic approach aimed at emancipating the Greek economy from the crisis of the current economic system. This approach should seek to accomplish the following goals: (a) to renegotiate Greece's existing loan agreement with the troika; (b) to establish an employment creation agenda through "employer of last resort" schemes; (c) to reconstruct and transform the existing banking system; and (d) to adopt a more flexible, more appropriate approach to the implementation of austerity and internal devaluation.

Arestis and Pelagidis (2010) note that the "postGreat Recession"-era policy has finally prevailed globally, especially around Europe; the UK and similar countries might find it even harder to administer an export-led policy medication to their economies. In Europe in particular, the near absence of a stimulus has indeed brought the Eurozone close to dissolution. According to the authors, the problem is that embarking on austerity increases risk of dreaded outcomes in Europe, including negative growth in gross domestic product, sovereign default, political instability and shuttered capital markets. Such outcomes make bank failures more likely, not less. They note that it is easier to understand the embrace of austerity in a political context. Namely, the emphasis on austerity has emerged even in countries with strong balance sheets despite the fact that one of history's most well-known lessons is that in times of recession, fiscal stimulus is the best medicine. They explain phenomena with the following facts; if state budgets are restricted, sovereign bond prices will rise, rescuing imperiled banks. In that way, moribund interbank lending will be resuscitated and government borrowing costs will decline. In another way, it is obvious that European politicians are incapable of directing stimuli towards productive public investment and the public continues to reject $\operatorname{tax}$ increases to cover the future deficits that would create a stimulus today. According to the author, the government should support postsecondary education, investment in clean energy, new transportation infrastructures and so on. Otherwise, austerity mania will hit us very hard.

According to Škare (2013), an important aspect of fiscal austerity dates from approximately 375 BC, as seen in Kautilya's papers. Škare states that Kautilya opposed any strict fiscal policy measure, recognizing the negative effects of fiscal austerity-including generating both negative business cycles and "deficit fetishists" - that are clearly implied in his remarks. According to Škare, fiscal austerity is a road to economic distress because it ruins personal wealth and the power of consumption-generating business cycles. The author stresses that Philips's theory (1962) of economy as a science attempts to explain how the system works. In that paper, he notes that production activities are the main imperative when creating wealth and therefore, banks and economic policy makers should work on defining an interest rate that will reflect a reasonable rate of profit and risk. With respect to Kautilya's critique, he notes that Kautilya was aware of the market's negative consequences, for example, the legacy of tax 
and tax policy (higher taxes lead to lower consumption, lower production, and therefore, higher unemployment and economic cycles). Accordingly, Kautilya had no intention of using tax policy for income (re) distribution. His idea was to limit profit margins in the market (by taxing extra profit) while either limiting or protecting markets that generate an unfair income distribution.

Furthermore, Škare (2010; a) shares the opinion and legacy of A.W. Philips (1962) that none of the economic policies designed and adopted without the knowledge of quantitative economic relationships between the three most important economic variables (unemployment/ inflation /output) can be considered effective and appropriate economic policy. Otherwise, the knowledge of such quantitative relations could be used to design a set of monetary and fiscal policies with the able to ensure a sustainable, long-term combination of unemployment, inflation and growth. One way to confirm this approach is to conduct an historical examination of economic crises; for example, over the last 200 years, the United States has experienced more than 47 of them. The author states that world economies reacted differently to the economic crisis, although the budget deficit, social rights and strong state intervention can be reduced under a common denominator. According to the author, the budget stabilization that becomes the exclusive goal during a crisis actually deepens and prolongs the crisis. Furthermore, Škare (2010; b) analyzes how a bad exchange rate policy and the 1993 stabilization program placed Croatia found itself in the steel embrace of the golden triangle. Because of Croatia's exchange rate and credit policy, its current monetary policy is limited and it cannot perform its appropriate role in times of crisis. Therefore, fiscal policy alone cannot be the solution-i.e., cutting the budget is neither the key issue nor a possible solution. According to the author, "cutting " aggregate consumption would lead to a further decline in production and would generate a vicious circle of poverty. The rationalization of public finances is a necessary but not a sufficient condition for economic growth. Unemployment/ inflation/output are the only three variables that simultaneously act as policy objectives and instruments of economic policy, and knowledge of their quantitative relationship is essential to understanding how the system works. In conclusion, Škare believes it necessary to perform fiscal consolidation in a manner that has a positive effect on employment and production.

Antonakakis and Collins (2014) examine the impact of fiscal austerity on suicide in Greece. The responsiveness of suicide to fiscal austerity is established as a means of providing policy guidance on the extent of suicidal behavior associated with different fiscal austerity measures.

Branas et al. (2015) also discuss the health effects of fiscal austerity. More specifically, they analyze the impact of fiscal austerity and prosperity events on suicide in Greece using a 30-year interrupted time-series analysis and suggest that the consideration of future austerity measures should give greater weight to unintended mental health consequences and the public messaging of austerity policies and related events.

Despite numerous studies, this complex topic has not been the subject of a sufficient methodological exploration. Due to the lack of methodological implementation and statistical data, it is not surprising that there is no consensus on the application of austerity policy.

\section{Data and analysis}

The financial turmoil of 2007/2008 affected many countries, especially EU and transitional countries, but the roots of the structural difficulties and fiscal unsustainability confronting national economies were in place long before the world crisis.

Aristovnik and Berčić (2007) state that in the early stage of transition, the need for major fiscal reforms was generally underestimated. According to them, the need to rapidly privatize and "get the state out of the economy" were emphasized, unlike more recent practices, which have admitted the need for an entirely new system, new fiscal institutions, new skills, technical knowledge and political capital.

In most of the transitional countries, including Croatia, spillover of the financial crisis into the real sector has resulted in recession. The effects of the national economy's primary problems are evident in movements in the dynamics of the real GDP growth rate, the structure of demand, and trends in both unemployment and central government finance (see Tab below). The extreme growth of public deficits and debt called into question the sustainability of public finance. 
Table 1. Annual percentage growth rate of GDP in Croatia, 2001-2013

\begin{tabular}{|c|c|c|c|c|c|c|c|c|c|c|c|c|c|}
\hline & 2001 & 2002 & 2003 & 2004 & 2005 & 2006 & 2007 & 2008 & 2009 & 2010 & 2011 & 2012 & 2013 \\
\hline $\begin{array}{l}\text { GDP growth } \\
\text { (annual) } \%\end{array}$ & 3.7 & 4.9 & 5.4 & 4.1 & 4.3 & 4.9 & 5.1 & 2.1 & -6.9 & -2.3 & -0.2 & -1.9 & -1.0 \\
\hline
\end{tabular}

Note: Adapted from "GDP growth (annual \%)", by The World Bank (2014g). Retrieved from http://data.worldbank.org/indicator/NY.GDP.MKTP.KD.ZG

Table 2. Structure of demand in Croatia, 2000, 2012 (\% of GDP)

\begin{tabular}{lcc}
\hline & $\mathbf{2 0 0 0}$ & $\mathbf{2 0 1 2}$ \\
\hline Household final consumption expenditure & 62 & 60 \\
General government final consumption expenditure & 21 & 20 \\
Gross capital formation & 20 & 19 \\
Export of goods and services & 37 & 42 \\
Imports of goods and services & 40 & 41 \\
Gross savings & 19 & 19 \\
\hline
\end{tabular}

Note: Adapted from "World Development Indicators: Structure and Demand", by The World Bank (2014a). Retrieved from http://wdi.worldbank.org/table/4.8

To reduce the negative effects of these economic developments, an immediate economic-policy response was requested. The direction of economic policy was greatly influenced by Croatia's accession to the EU on July 1, 2013, because of newly imposed restrictions known as convergence criteria. The burden of adjusting the Washington consensus and adopting new convergence criteria mostly fell onto the labor market and income redistribution. Specifically, by applying the policy of "fiscal austerity" or "sharp cuts" to public finances, economic actors have refocused the objectives of economic policy from increased domestic production, competitiveness, and employment to solving the problems of the budget deficit and public debt, which had negative effects on welfare. The main instrument of economic policy becomes fiscal consolidation, whereas monetary policy is neutral and procyclical. The effects of this "austerity experiment" are questionable given increasing unemployment, the decline in aggregate demand, increasing public debt and the lack of revenue to repay that debt (See Tab below). We begin our analysis with the effects of the primary problems in Croatia's economy, to determine whether fiscal austerity contributes to Croatia's economic growth.

\section{Results}

Structural imbalances are reflected in the decline in annual percentage growth rate of GDP recorded by Croatia records since the beginning of its transition. The first half of the decade 1991-2000 showed a decrease in economic activity caused by war, destruction and the transition to a market economy (along with the disintegration of the Eastern European market and the beginning of the disintegration of the common Yugoslav market). The second part of the decade 20012010 (see Table 1) marked a new development cycle with growth that continued until 2009 and the financial crisis, after which we see a contraction of growth.

As noted by Mendonca (2014), the European crisis presents a structural dimension that has been developing for years and has gained momentum primarily from an inability to respond in a timely way to the factors that caused the shocks.

It is important to emphasize that the pre-2009 economic growth was built on an unsustainable growth model based on household consumption rather than investment spending, thus creating the foundation for the crisis. These negative developments are interpreted in the Table 2. 
Table 3. Gross investment in fixed assets by technical composition, 2000, 2011, 2012

\begin{tabular}{lccc}
\hline & Equipment (\%) & Construction works (\%) & Other (\%) \\
\hline 2000 & 4.6 & 52.3 & 6.1 \\
2011 & 37.06 & 52.15 & 10.79 \\
2012 & 38.26 & 50.61 & 11.13 \\
\hline
\end{tabular}

Note: Adapted from "Statistical yearbook of Croatia 2002", by Croatian Bureau of Statistics (2002). Retrieved from www.dzs.hr/ Hrv_Eng/ljetopis/2002/sljh2002.pdf; "Statistical yearbook of Croatia 2013", by Croatian Bureau of Statistics (2013). Retrieved from www.dzs.hr/Hrv_Eng/ljetopis/2013/sljh2013.pdf; "Statistical yearbook of Croatia 2014, by Croatian Bureau of Statistics (2014). Retrieved from www.dzs.hr/Hrv_Eng/ljetopis/2014/sljh2014.pdf

Table 4. Unemployment rates (\%) 2005-2013

\begin{tabular}{lccccccccc}
\hline Countries & $\mathbf{2 0 0 5}$ & $\mathbf{2 0 0 6}$ & $\mathbf{2 0 0 7}$ & $\mathbf{2 0 0 8}$ & $\mathbf{2 0 0 9}$ & $\mathbf{2 0 1 0}$ & $\mathbf{2 0 1 1}$ & $\mathbf{2 0 1 2}$ & $\mathbf{2 0 1 3}$ \\
\hline EU-28 & 9.0 & 8.2 & 7.2 & 7.0 & 9.0 & 9.6 & 9.6 & 10.4 & 10.8 \\
\hline Euro area (EA-18) & 9.1 & 8.4 & 7.5 & 7.6 & 9.5 & 10.1 & 10.1 & 11.3 & 12.0 \\
\hline Bulgaria & 10.1 & 9.0 & 6.9 & 5.6 & 6.8 & 10.3 & 11.3 & 12.3 & 13.0 \\
\hline Czech Republic & 7.9 & 7.1 & 5.3 & 4.4 & 6.7 & 7.3 & 6.7 & 7.0 & 7.0 \\
\hline Croatia & 12.8 & 11.4 & 9.6 & 8.4 & 9.1 & 11.8 & 13.5 & 15.9 & 17.2 \\
\hline Romania & 7.2 & 7.3 & 6.4 & 5.8 & 6.9 & 7.3 & 7.4 & 7.0 & 7.3 \\
\hline Slovakia & 16.4 & 13.5 & 11.2 & 9.6 & 12.1 & 14.5 & 13.7 & 14.0 & 14.2 \\
\hline Slovenia & 6.5 & 6.0 & 4.9 & 4.4 & 5.9 & 7.3 & 8.2 & 8.9 & 10.1 \\
\hline Hungary & 7.2 & 7.5 & 7.4 & 7.8 & 10.0 & 11.2 & 10.9 & 10.9 & 10.2 \\
\hline Poland & 17.9 & 13.9 & 9.6 & 7.1 & 8.1 & 9.7 & 9.7 & 10.1 & 10.3 \\
\hline
\end{tabular}

Note: Adapted from "Unemployment rate by sex and age groups - annual average, \%" by Eurostat (2015). Retrieved from http://appsso.eurostat.ec.europa.eu/nui/show.do?dataset=une_rt_a\&lang=en

The policy advanced by the creators of the Washington consensus has ensured liberalization and deregulation of the capital markets, resulting in increased foreign borrowing and significant credit expansion. Most of the spending in 2000 and 2012 was directed at household consumption typically financed by foreign borrowing-62\% and $60 \%$, respectively-whereas the lowest percentage-19\%-was directed at gross savings. The effect of the recession is primarily reflected by the decline in household consumption expenditures (62\% in $2000 ; 60 \%$ in 2012 ) and government consumption expenditures ( $21 \%$ in $2000,20 \%$ in 2012). The inability of even the private sector to generate aggregate demand is confirmed by the data regarding share in gross savings. Indeed, households have a higher propensity during recessions to save than to invest. Gross capital formation (19\% in 2000, $19 \%$ in 2012) primarily includes investments in roads, railways, buildings and so on, which ultimately do not create additional value (see Table 3 ).

The table shows that in 2000 and 2011-2012, the largest share of gross investment in fixed-assets construction works was $52.3 \%$ in $2000,52.15 \%$ in 2011 , and $50.61 \%$ in 2012 , whereas there was a significantly lower proportion of investment in equipment with only $41.6 \%$ in $2000,37.06 \%$ in 2011 and $38.26 \%$ in 
Table 5. Central government finances, revenues and expenses, 2000, 2012 (\% of GDP)

\begin{tabular}{lcccc}
\hline & Revenue 2000 & Revenue 2012 & Expense 2000 & Expense 2012 \\
\hline Croatia & 35.3 & 33.9 & 38.7 & 36.6 \\
\hline
\end{tabular}

Note: Adapted from "World Development Indicators: Central government finances", by The World Bank (2014b). Retrieved from http://wdi.worldbank.org/table/4.12

Table 6. Structure of central government expenses, 2000

\begin{tabular}{lccccc}
\hline Countries & $\begin{array}{c}\text { Goods and } \\
\text { services }(\% \text { of } \\
\text { expenses) }\end{array}$ & $\begin{array}{c}\text { Compensation of } \\
\text { employees }\end{array}$ & $\begin{array}{c}\text { Interest } \\
\text { payments }\end{array}$ & $\begin{array}{c}\text { Subsidies and } \\
\text { other transfers }\end{array}$ & Other expenses \\
\hline Croatia & 24 & 26 & 4 & 43 & 3 \\
\hline
\end{tabular}

Note: Adapted from "World Development Indicators: Central government expenditure", by The World Bank (2014c). Retrieved from http://wdi.worldbank.org/table/4.13

2012. To achieve a "big push", it is necessary to initially begin to develop investment projects and to invest in equipment that will not only create new added value but also influence the growth of exports. As noted above, the burden of adjusting to the Washington consensus and adopting EU rules mostly affected the labor market and the redistribution of income, as indicated by the Table 4 .

Most countries in the observed period before the financial crisis (2005-2008) note a decrease in unemployment; following the financial crisis of 2008, however, the massive contraction of credits, reduced imports, and reduced demand for exports negatively affected both production and employment, as confirmed by the experiences of Poland, Romania, Hungary and so on. Low agricultural productivity, low industrial productivity (i.e., deindustrialization), technological backwardness and the neglect of innovations, and negative investment trends related to capital expenditures have resulted in an increase in Croatia's for unemployment rate between 2008-2013; in 2013, Croatia reported the highest unemployment rate (17.2\%) among not only the observed transition countries but also the EU countries overall. This decline in production and employment has resulted in even higher borrowing and lower revenues than expenses, as indicated by the Table 5 .
This table shows that in 2000 and 2012, Croatia recorded higher expenses than revenues. Unlike in 2000, in 2012 the percentage of revenue decreased from $35.3 \%$ to $33.9 \%$, although the table shows that expenses declined from $38.7 \%$ to $36.6 \%$. Croatia's lack of sufficient revenue to ensure the sustainability of its public debt has created a demand for austerity. The tables below show that Croatia spends the most on current, short-term expenditures, namely, subsidies and other transfers that clearly cannot be the subject of long-term financing considering that they are most often settled by increased borrowing.

Accordingly, in 2000, the largest portion of Croatias expenditures was attributable to subsidies and other transfers at $43 \%$ and the smallest portion was attributable to interest payments at $4 \%$ and other expenses at $3 \%$.

The largest share of Croatia's expenditures in 2012 was attributable to subsidies and other transfers at 54\% and the smallest share was attributable to interest payments at $7 \%$ and other expenses at $5 \%$. As opposed to the situation in 2000, in 2012 the share of goods and services declined from $24 \%$ to $8 \%$, earmarks for interest payments increased from $4 \%$ to $7 \%$, and subsidies and other transfers increased from $43 \%$ to $54 \%$, once again indicating the problem of public debt financing. The following table indicates the structure of the Croatian government's revenues. 
Table 7. Structure of central government expenses, 2012

\begin{tabular}{lccccc}
\hline Countries & $\begin{array}{c}\text { Goods and } \\
\text { services (\% of } \\
\text { expenses) }\end{array}$ & $\begin{array}{c}\text { Compensation of } \\
\text { employees }\end{array}$ & $\begin{array}{c}\text { Interest payments } \\
\text { omplidies and }\end{array}$ & $\begin{array}{c}\text { Subsidiansfers } \\
\text { other expenses }\end{array}$ \\
\hline Croatia & 8 & 26 & 7 & 54 & 5 \\
\hline
\end{tabular}

Note: Adapted from "World Development Indicators: Central government expenditure", by The World Bank (2014c). Retrieved from http://wdi.worldbank.org/table/4.13

Table 8. Central government revenues, 2000, 2012

\begin{tabular}{ccccccc}
\hline $\begin{array}{c}\text { Taxes on income, } \\
\text { profits and } \\
\text { capital gains } \\
\text { (\% of revenue) }\end{array}$ & $\begin{array}{c}\text { Taxes on goods } \\
\text { and services } \\
\text { (\% of revenue) }\end{array}$ & $\begin{array}{c}\text { Taxes on } \\
\text { international } \\
\text { trade } \\
\text { (\% of revenue) }\end{array}$ & $\begin{array}{c}\text { Other taxes } \\
\text { (\% of revenue) }\end{array}$ & $\begin{array}{c}\text { Social } \\
\text { contributions } \\
\text { (\% of revenue) }\end{array}$ & $\begin{array}{c}\text { Grants and other } \\
\text { revenue }\end{array}$ \\
\hline 2000 & 9 & 46 & 6 & 1 & 32 & 5 \\
2012 & 8 & 47 & 2 & 1 & 34 & 9 \\
\hline
\end{tabular}

Note: Adapted from "World Development Indicators: Central government revenues", by The World Bank (2014d). Retrieved from http://wdi.worldbank.org/table/4.14

Table 9. Structure of output in Croatia, 2000, 2012

\begin{tabular}{ccccc}
\hline & Agriculture (\%) & Industry (\%) & Manufacturing (\%) & Services (\%) \\
\hline 2000 & 6 & 29 & 18 & 64 \\
2012 & 4 & 27 & 14 & 68 \\
\hline
\end{tabular}

Note: Adapted from "World Development Indicators: Structure of output", by The World Bank (2014e). Retrieved from http:// wdi.worldbank.org/table/4.2

The revenue side primarily reflects shortfalls in income tax and taxes on international trade, which increases social contributions, grants and other revenue.

The earnings model based on industrialization, exports, savings and investments has been replaced by a model based on imports and deindustrialization, as indicated by the Table 9 .

This table shows that from 2000-2012 agriculture, industry, and manufacturing showed a decreasing trend, whereas services are the only sector that showed an increasing trend. The structure of investment and output reveals an unsustainable path to economic growth and development. More specifically, deindus- trialization, technological backwardness, and directing investment policy towards infrastructure development and services instead of capital expenditures (education, health, development centers) created the basis for increased public debt (see Table 10).

The continuous growth of Croatia's deficit caused an increase in public debt: by 2013 , it reached $67.4 \%$. The table shows that public debt is a matter of concern not only because of its amount but also because of the dynamics of its movement (i.e., the growth rate of total public debt was higher than the growth rate of GDP). Croatia's long-term deficit also indicates structural problems with the national economy. More specifical- 
Table 10. Budget deficit and public debt in Croatia, 2007-2013

\begin{tabular}{lccccccc}
\hline & $\mathbf{2 0 0 7}$ & $\mathbf{2 0 0 8}$ & $\mathbf{2 0 0 9}$ & $\mathbf{2 0 1 0}$ & $\mathbf{2 0 1 1}$ & $\mathbf{2 0 1 2}$ & $\mathbf{2 0 1 3}$ \\
\hline $\begin{array}{l}\text { Public debt (\% } \\
\text { of GDP) }\end{array}$ & 33.3 & 30.0 & 36.6 & 45.0 & 52.0 & 55.9 & 67.1 \\
$\begin{array}{l}\text { Deficit (\% of } \\
\text { GDP) }\end{array}$ & -1.9 & -1.9 & -5.4 & -6.4 & -7.8 & -5 & -4.9 \\
\hline
\end{tabular}

Note: Adapted from "World Development Indicators: Structure of demand", by The World Bank (2014a). Retrieved from http:// wdi.worldbank.org/table/4.8

Table 11. Budget deficit of selected countries, 2012

\begin{tabular}{lc}
\hline Countries & Cash surplus deficit (\% of GDP) \\
\hline Czech Republic & -2.5 \\
Germany & 0.1 \\
Slovenia & -3.6 \\
Spain & -9.0 \\
Portugal & -7.0 \\
Italy & -3.1 \\
Greece & -9.4 \\
UK & -5.8 \\
USA & -7.5 \\
\hline
\end{tabular}

Note: Adapted from "Cash surplus deficit (\%of GDP)", by The World Bank (2014f). Retrieved from http://data.worldbank.org/ indicator/GC.BAL.CASH.GD.ZS

ly, negative economic developments in Croatia-especially after 1994 - have a strong hold over Croatia's economic policy, which aimed to stabilize prices and exchange rates rather than to spur development. Croatia's exchange rate policy changed the structure of the economy: the import sector became dominant, resulting in both debt growth and deficit growth in Croatia's current account balance. It is important to emphasize, however, that Croatia's exchange rate policy was not the only cause of its economic problems. Very important are the structure of deficit and deficit financing. From the table below, it is clear that other countries experience high rates of deficit compared to their to GDP; however, the manner in which the country finances its deficit and the purpose of the country's public debt are both important.
The strongest world economies-for example, the United States and the U.K.-finance economic recovery by growing their deficits, whereas the EU countries takes the opposite approach, i.e., they prioritize the fight against deficits. Significantly, in most transition countries, the financial crisis and declining GDP, not structural adjustments, have affected declining deficits due to lower imports.

\section{Discussion}

During the debt crisis, most of the European countries affected, including Croatia, implemented fiscal discipline policies to reduce debts. Most commonly, however, measures that intended to achieve reduced debt and an economic recovery resulted in increased debt and increased unemployment (Table 12). Promotion of the 
Table 12. Economic effects of austerity

\begin{tabular}{lcc}
\hline & $\mathbf{2 0 1 2}$ & $\mathbf{2 0 1 3}$ \\
\hline Budget deficit (\% of GDP) & -5 & -4.9 \\
Public debt (\% GDP) & 55.9 & 67.1 \\
Real GDP growth rate & -1.9 & -1.0 \\
Unemployment rate (\% GDP) & 15.9 & 17.2 \\
\hline
\end{tabular}

Note: Adapted from "World Development Indicators: Structure of demand", by The World Bank (2014a). Retrieved from http:// wdi.worldbank.org/table/4.8; "GDP growth (annual \%)", by The World Bank (2014g). Retrieved from http://data.worldbank. org/indicator/NY.GDP.MKTP.KD.ZG; "Unemployment rate by sex and age groups - annual average, \%" by Eurostat (2015). Retrieved from http://appsso.eurostat.ec.europa.eu/nui/show.do?dataset=une_rt_a\&lang=en

The vast majority of the factors implicated by austerity are not included in these indicators.

"sharp cuts" policy-i.e., a policy in which the main instrument of economic policy is fiscal consolidation, whereas monetary policy is neutral and pro-cyclicalhas created negative effects. Those negative effects have been particularly severe with respect to employment and citizens' standard of living, most notably for citizens who are at the bottom "of the scale." Therefore, we must ask what has happened to the goal of reduced unemployment and increased prosperity. According to Bejaković (2013), a significant number of Croatians suffer from difficult social conditions and lack adequate access to public goods and services. With increased unemployment and budgetary problems, we can expect further deterioration of social conditions.

Indeed, Croatia has one of the highest unemployment rates in the EU. Given the dynamics of movement and the amount of public debt, it is important to note the importance of rationalizing-not necessarily reducing-public spending. The funds freed by rationalization can be used for active employment policy measures, co-signing loan obligations, improving general liquidity, etc. Based on an analysis of macroeconomic indicators, it can be concluded that the objectives of increasing domestic production and economic growth are mutually transversal with the aim of solving budget deficits by applying austerity policy. If we reach the bottom of the business cycle by reducing wages, we will not see an increase in employment, national income, exports and competitiveness, as demonstrated in the previous tables. Instead, we will see a decrease in economic growth. Therefore, this author supports Keynes's idea of the impact of business cycles on the application of austerity. In translated terms, austerity can have both positive and negative effect on the economy depending on the business cycle. To avoid repeating the negative experience of the PIGS countries, Croatia-like South Korea-needs to create a macroeconomic environment based on industrialization, production and employment, thus solving the deficit problem. As noted by Radulescu and Druica (2014), in today's world of financial and economic turmoil, labor is a key resource that (in their opinion) is considered to have relatively high education and training levels and a strong scientific base. The above referenced steps will result in higher wages and productivity, which is important for economic growth. Blažević (2013) notes that from the public policy perspective, the minimum wage is an attractive tool because it carries strong political symbolism without requiring increased public expenditures. She concludes, however, that most empirical studies find that the minimum wages has effects that are both negative and self-interested.

When an economic policy experiences radical changes, its objectives must be redefined.

\section{Conclusion}

Mainstream economic theory and neoliberal economic policy were called into question after the global financial crisis highlighted their limitations. No consensus on the implementation of fiscal austerity has been achieved be- 
cause despite numerous studies, this complex topic is not been the subject of sufficient methodological exploration. Emphasis should be placed on defining the methodology of austerity and gathering statistical data to influence the implementation of social transfer policies. In addition, it is necessary to adopt a hybrid approach to fiscal and monetary policy that comprehends both economic laws and quantitative economic relations. The outcome of this research should affect the transitional countries' immediate decision-making related to the implementation of social policies. It can serve also as a basis for further research. Implications, limitations, and directions for further research are offered.

\section{References}

Aglietta, M. (2012). Zone Euro, Eclatement ou Federation. Paris: Michalon.

Antonakakis, N. and Collins, A. (2014). The impact of fiscal austerity on suicide: on the empirics of a modern Greek tragedy. Social Science and Medicine Journal, 112, 39-50.

Arestis, P., Pelagidis T. (2010). Absurd Austerity Policies in Europe. Challenge, 53 (6), 54-61.

Aristovnik, A., Berčić, B. (2007). Fiscal Sustainability in Selected Transition Countries. (MPRA, No.122). University Library of Munich, Germany.

Bejaković, P. (2013). The importance of social transfers in reducing poverty in Croatia. Economic Research, [Special Issue], 103-116.

Blažević, S. (2013), Is employment decreasing due to minimum wage increase? Economic Research, 26 (1), 69-100.

Blyth, M. (2013). Austerity; The history of a dangerous idea. Oxford, UK: Oxford University Press.

Branas, C. C., Kastanaki, A. E., Michalodimitrakis, M., Tzougas, J., Kranioti, E. F., Theodorakis, P. N., Carr, B.G., \& Wiebe, D. J. (2015). The Impact of Economic austerity and prosperity events on suicide in Greece: A30-Year Interrupted TimeSeries- Analysis. Health Policy, 5 (1), (n.d.) DOI:10.1136/bmjopen-2014-005619.

Calcagno, A. (2012). Can austerity work? Review of Keynesian Economics, [Inaugural Issue], 24-36.

Constantinos, A. , Nellis, J. G. (2013). Challenging the Raison d'etre of Internal Devaluation in the Context of the Greek Economy. Panoeconomicus, 60 (6), 813-836.
Chang, H. J. (2011). 23 Things they don't tell you about capitalism. London, UK: Penguin Group.

Chang, H. J., (2008). Bad Samaritans. The Myth of Free Trade and the Secret History of Capitalism. New York, NY: Bloomsbury Press.

Croatian Bureau of Statistics (2002). Statistical yearbook of Croatia 2002. Retrieved from http:// www. dzs.hr/Hrv_Eng/ljetopis/2002/sljh2002.pdf

Croatian Bureau of Statistics (2013). Statistical yearbook of Croatia 2013. Retrieved from http:// www. dzs.hr/Hrv_Eng/ljetopis/2013/sljh2013.pdf

Croatian Bureau of Statistics (2014). Statistical yearbook of Croatia 2014. Retrieved from http:// www. dzs.hr/Hrv_Eng/ljetopis/2014/sljh2014.pdf

International Monetary Fund (2012). Fiscal Monitor (April 2012). Balancing, Fiscal Policy Risks. Retrieved from http://www.imf.org/external/pubs/ $\mathrm{ft} / \mathrm{fm} / 2012 / 01 / \mathrm{pdf} / \mathrm{fm} 1201 . \mathrm{pdf}$

Keynes, J. M. (1936), The General Theory of Employment, Interest and Money. London, UK: MacMillan.

Konzelmann, S. J. (2012). The Economics of Austerity (Working Paper). Centre for Business Research. Retrieved from http://eprints.bbk.ac.uk/5867

Minksy, H. P. (1992). The financial instability hypothesis (Working Paper No. 74). The Jerome Levy Economics Institute of Bard College.

Mendonca, A. (2014). The European Crisis and Global Economy Dynamics: Continental Enlargement versus Atlantic Opening. Panoeconomicus, 61 (5), 543-569.

Ogujiuba, K. K., Ehigiamusoe, K. (2014). Capital Budget Implementation in Nigeria: Evidence from the 2012 Capital Budget. Contemporary Economics, 8 (3), 243-348.

Papadimitriou, D.B.., Hannsgen, G (2012). A Brief Guide to the US stimulus and Austerity Debates, One-Pager/No. 35.

Phillips, A.W. (1962). Employment, Inflation and Growth. Economica, 29 (113), 1-16.

Radulescu, M., Druica, E. (2014). The impact of fiscal policy on foreign direct investments. Empiric evidence from Romania, Economic Research, 27 (1), 86-106.

Sharma, S. (2002). Economics does Matter: About Economics and Economists, Mikrorad, Zagreb.

Sharma, S. (2013). Making the Social World: A retrospect. Economic Research, 26 (1), 243-256. 
Škare, M. (2013). The missing link: From Kautilya s The Arthashastra to modern economics. The Journal of Philosophical economics, 6 (2), 2-31.

Škare, M. (2010a). Can there be a golden "triangle" of internal equilibrium? Journal of Policy Modeling, 32 (4), 562-573

Škare, M.(2010b). Hrvatska u „Čeljusti“ zlatnog trokuta [Croatia in the Golden triangle trap]. Economics, 1 (17), 79-100.

UNCTAD (2011). Trade and development report. Retrieved from http://unctad.org/en/Docs/tdr2011_en.pdf

The World Bank (2014a). World Development Indicators: Structure of demand. Retrieved from http:// wdi.worldbank.org/table/4.8

The World Bank (2014b). World Development Indicators: Central government finances. Retrieved from http://wdi.worldbank.org/table/4.12

The World Bank (2014c). World Development Indicators: Central government expenditure. Retrieved from http://wdi.worldbank.org/table/4.13

The World Bank (2014d). World Development Indicators: Central government revenues. Retrieved from http://wdi.worldbank.org/table/4.14

The World Bank (2014e). World Development Indicators: Structure of output. Retrieved from http:// wdi.worldbank.org/table/4.2

The World Bank (2014f). Cash surplus deficit (\%of GDP). Retrieved from http://data.worldbank.org/ indicator/GC.BAL.CASH.GD.ZS

The World Bank (2014g). GDP growth (annual \%). Retrieved from http://data.worldbank.org/indicator/ NY.GDP.MKTP.KD.ZG

The World Bank (2012). World Development Indicators 2012. Retrieved from http://data.worldbank. org/sites/default/files/wdi-2012-ebook.pdf

Eurostat (2014a). General Government Gross Debt. Retrieved from http://epp.eurostat.ec.europa.eu/ tgm/table.do?tab=table\&init $=1$ \&language $=$ en $\& \mathrm{p}$ code $=$ tsdde 410 \&plugin $=1$

Eurostat (2014b). General Government Gross Deficit/ Surplus. Retrieved from

http://epp.eurostat.ec.europa.eu/tgm/table.do?tab=table \&init $=1$ \&language $=$ en \&pcode $=$ tec 00127 \&plugin $=1$

Eurostat (2015). Unemployment rate by sex and age groups - annual average, \%. Retrieved from http://appsso.eurostat.ec.europa.eu/nui/show. do?dataset=une_rt_a\&lang=en
Zaman, K., Khilji, B. A., Awan, U., Ali, G., Naseem, I. (2014). Measuring pro poor sectoral analysis for Pakistan: trickle down? Economic Research, 27 (1), 713-728. 